\title{
Determinants of Executive Compensation
}

\author{
Albasita Syafna Al'azhary ${ }^{1}$ \\ ${ }^{1}$ Faculty of Economic-Universitas Negeri Jakarta-Indonesia \\ Suherman $^{2}$, Agung Dharmawan Buchdadi ${ }^{3}$ \\ ${ }^{2}$ Faculty of Economic-Universitas Negeri Jakarta-Indonesia \\ ${ }^{3}$ Faculty of Economic-Universitas Negeri Jakarta-Indonesia
}

Correspondence: albasitaalazhary@gmail.com

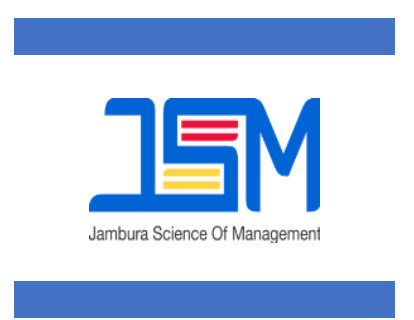

JSM

Volume 4

Number 1

January 2022.

Received on 14 July 2021

Revised on 21 July 2021

Accepted on 22 July 2021

The journal allows the

authors to hold the copyright

without restrictions and

allow the authors to retain

publishing rights without

restrictions. Authors retain

copyright and grant the

journal right of first

publication with the work

simultaneously licensed

under a creative commons

attribution 4.0 international

license.

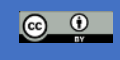

DOI: 10.37479

\section{ABSTRACT}

Purpose: The object of this research focuses on executive compensation, which is a form of appreciation for the agent's contribution as the party responsible for the company performance and the improvement of the walfare of the principals. The aims of this study is to determine the effect of profitability and leverage on executive compensation in non financial companies listed in Indonesia Stock Exchange for the period 2017 - 2019.

Design/Methodology/Approarch: Population of this study is non financial companies listed in Indonesia Stock Exchange for the period 2017 - 2019 with a sample by non financial listed in Kompas100 index to represent the existing population. Independent variables used in this study are profitability which is measured by return on assets (ROA) and leverage which is measured by debt to equity ratio (DER). Dependent variable used in this study is executive compensation which is measured by total remuneration of president director. This study also used control variables such as executive age, executive gender and executive tenure. The sampling method of this study is a purposive sampling. The research model used is panel data with fixed effect model approach.

Findings: The findings have shown that profitability has a negative significant effect on executive compensation. It is also noted that the lower level of the company's debt, the larger the amount of executive compensation. These findings shed the light on research on agency theory that compensation on performance is not valid in Indonesia.

Keywords: CEO Compensation; Profitability; Leverage; CEO Age; CEO Gender; CEO Tenure

\section{INTRODUCTION}

In the last decade, the issue of executive compensation has been widely debated in various perspectives. According to Locke (2020) and McGregor (2020), debate over the issue of executive compensation occurred in the United States due to increased executive compensation even though there has been a decline in 
company performance, massive layoffs and cuts in wages. Friana (2019) stated in Indonesia as the Minister of Transportation and the Minister of BUMN stated that the odd remuneration that had occurred in several institution in the last three years was due to policies of remuneration that were not based on company performance and were not in accordance with the regulation of Financial Service Authority No. 45 of 2015, such as the compensation scandal commited by president director and a number of his subordinates in the midst of company's condition which lost billion rupiah and several other cases such as the remuneration received by director which in reality the company suffered a net loss of hundreds million rupiah (Arief, 2019). Another case is reforms in China that raises executive compensation issue and examine the determinants of executive compencastion (Conyon et al., 2015; Firth et al., 2016; Ullah et al., 2020). Based on this explanation, this occurs due to the compensation system mechanism that is not based on company performance and inconsistencies with existing regulation. The issue of compensation received considerable attention as a form of emphasis on company performance which indicates the company's success, ability to generate long-term benefit, as well as to excel in global competition.

According to Parimana \& Wishada (2015), executives or who are known as president director in Indonesia, are fully responsible for managing the company in order to achieve the company survival. Many executive performance is associated with the view that basically an individual will always choose and maximize his own self-opportunity (not altruistic) interest which causes agency conflict (Setyawan \& Devie, 2017). Many studies have been conducted to investigate the determinant of executive compensation, aligning agent interest and principals through 'pay-for-performance' in order to overcome agency conflict. Essen et al (2015) and Shah et al (2019) investigate the determinant of executive compensation such as firm profitability as a factor that can aligning agent and principals interest. Field et al (2016) used leverage in their research to assess company performance as well as debt ratio as a requirement to consider executive compensation.

Topic of executive compensation has not been widely discussed in Indonesia, especially regarding the effect of profitability and leverage as company performance reflection in influencing executive compensation. This research will have the contribution regarding the effect of profitability and leverage on the executive compensation.

\section{Effect of profitability on executive compensation}

Profitability defined as a ratio that measures a company's ability to generate profits at certain level of sales, assets and capital stock (Hakim \& Sugianto, 2018). We note that profitability variable positively influences the executive compensation by ROA proxies (Buigut et al., 2015; Khanna, 2016; Mardiyati et al., 2013; Sheikh et al., 2018; Wang et al., 2013). Large companies have large-scale 
inventory to support large-scale sales, which will provide large amount of profit and when company's profit larger, it will be increase company's ability to pay large amount of executives compensation (Parthasarathy et al., 2011).

$\mathrm{H}_{1}$ : Profitability will have significantly positive effect on executive compensation.

\section{Effect of leverage on executive compensation}

Leverage is defined as a ratio that measures the company's ability to pay all of its obligation, both short and long term (Lin et al., 2018). We note that leverage variable negatively influences the executive compensation by DER proxies (Dahiya, 2018). Companies with high leverage have large interest payments that lead to lower profit, and therefore have an impact on lower compensation package contract (Rodrigues \& Simões, 2017). Companies with low leverage ratio have high investment opportunities, thus providing higher total compensation to executives (Lin et al., 2013).

$\mathrm{H}_{2}$ : Leverage will have significantly negative effect on executive compensation.

\section{METHODS}

\section{Definition of Variables}

Table 1. Definition of Variables

\begin{tabular}{|c|c|c|c|}
\hline No & Variable & Concept & Indicator \\
\hline 1. & $\begin{array}{c}\text { Executive } \\
\text { Compensation }\end{array}$ & $\begin{array}{l}\text { Amount of } \\
\text { annual } \\
\text { compensation or } \\
\text { remuneration } \\
\text { received by a } \\
\text { President } \\
\text { Director }\end{array}$ & $\begin{array}{c}\text { Total compensation of President } \\
\text { Director consist of basic salary, } \\
\text { allowances and bonuses reported in } \\
\text { the annual report }\end{array}$ \\
\hline 2. & $\begin{array}{l}\text { Profitability } \\
\text { (ROA) }\end{array}$ & $\begin{array}{l}\text { Ability of } \\
\text { company's assets } \\
\text { to generate net } \\
\text { profit }\end{array}$ & $R O A=\frac{\text { Net income after tax }}{\text { Total assets }}$ \\
\hline 3. & $\begin{array}{l}\text { Leverage } \\
\text { (DER) }\end{array}$ & $\begin{array}{l}\text { Ability of } \\
\text { company's } \\
\text { equity to } \\
\text { guarantee and } \\
\text { pay off the } \\
\text { company's debt }\end{array}$ & $\begin{array}{l}\text { Leverage } \\
=\frac{\text { Total debt for the previous year }(t-1)}{\text { Total equity for the previous year }(t-1)}\end{array}$ \\
\hline 4. & Executive Age & $\begin{array}{l}\text { Age of an } \\
\text { executive at the } \\
\text { time of serving } \\
\text { as an President } \\
\text { Director }\end{array}$ & Number of years of executive age \\
\hline
\end{tabular}




\begin{tabular}{|cclc|}
\hline 5. & $\begin{array}{c}\text { Executive } \\
\text { Gender }\end{array}$ & $\begin{array}{l}\text { Gender of } \\
\text { President } \\
\text { Director }\end{array}$ & 1 = Male, $0=$ Female \\
\hline & & Number of years \\
& an executive has & \\
held a position as & Number of years of executive tenure \\
Executive & as President Director \\
Tenure & & \\
& & \\
& & \\
& &
\end{tabular}

\section{Data}

The population in this study are non financial companies listed in Kompas100 Indonesia Stock Exchange. This study uses a purposing sampling method using annual report of the firm for the period 2017 $-2019$.

\section{Equation Model}

Regression 1: Compensation ${ }_{t}=\beta_{0}+\beta_{1} \mathrm{ROA}_{\mathrm{it}}+\beta_{2} \mathrm{DER}_{\mathrm{i}(\mathrm{t}-1)}$

Regression 2: Compensation ${ }_{t}=\beta_{0}+\beta_{1}$ ROA $_{i t}+\beta_{2}$ DER $_{i(t-1)}+$ $\beta_{3} \mathrm{CEO} \mathrm{AGE}_{\mathrm{it}}+\beta_{4} \mathrm{CEO} \mathrm{GENDER}_{\mathrm{it}}+$ $B_{5}$ CEO_TENURE ${ }_{\text {it }}$

\section{RESULTS}

\section{Descriptive Statistics}

The descriptive statistical result in Table 2 show executive compensation as dependent variable; profitability and leverage as independent variable; executive age, executive gender and executive tenure as control variable.

Table 2. Descriptive Statistics

\begin{tabular}{|lcccccc|}
\hline & $\begin{array}{c}\text { Executive } \\
\text { Compensation } \\
(\mathrm{Rp})\end{array}$ & $\begin{array}{c}\text { Profitability } \\
(\mathrm{ROA})(\%)\end{array}$ & $\begin{array}{c}\text { Leverage } \\
(\mathrm{DER}) \\
(\%)\end{array}$ & $\begin{array}{c}\text { CEO } \\
\text { Age } \\
(\text { Year })\end{array}$ & $\begin{array}{c}\text { CEO } \\
\text { Gender } \\
(\text { Dummy })\end{array}$ & $\begin{array}{c}\text { CEO } \\
\text { Tenure } \\
(\text { Year }\end{array}$ \\
\hline Mean & $\begin{array}{c}\mathrm{Rp} \\
5.799 .162 .174\end{array}$ & 5,30 & 0,50 & 56 & 1 & 5 \\
\hline Maximum & $\begin{array}{c}\mathrm{Rp} \\
19.500 .000 .000\end{array}$ & 46,30 & 0,90 & 80 & 1 & 39 \\
\hline Minimum & $\begin{array}{c}\mathrm{Rp} \\
455.439 .006\end{array}$ & $-105,90$ & 0,00 & 35 & 0 & 0 \\
\hline $\begin{array}{l}\text { Standard } \\
\text { Deviation }\end{array}$ & $\begin{array}{c}\mathrm{Rp} \\
4.199 .537 .697\end{array}$ & 11,46 & 0,20 & 7 & 0,21 & 6,21 \\
\hline Observation & 219 & 219 & 219 & 219 & 219 & 219 \\
\hline
\end{tabular}

Source: Data processed (2021)

The average of executive compensation is $\mathrm{Rp} 5,799,162,174$ and standard deviation of executive compensation is $\mathrm{Rp} \mathrm{4.199,537,697.}$ This indicates that executive compensation in the sample of non financial companies has low variability during the study period. The maximum value of executive compensation obtained from PT. Japfa Comfeed Indonesia Tbk. in 2019, due to an increase in executive compensation, company's net sales, Company's equity as well as an 
increase in the company's assets. The minimum value of executive compensation was obtained from PT. Indah Kiat Pulp and Paper Tbk. The average of ROA is $5.30 \%$ and standard deviation of ROA is $11.46 \%$, this indicating that ROA experienced fluctuating movements and high variability during the study period. The maximum value of ROA obtained from PT. Unilever Indonesia Tbk in 2018 was due to an increase in net sales and net profit in 2018. The minimum value of ROA obtained from PT. Matahari Putra Prima Tbk in 2017 was due to a decrease in sales performance as well as a net loss and impacted to close many outlets.

The average DER is $0.50 \%$ and standard deviation of DER is $0.20 \%$, this indicating that non financial companies have a low DER variability. The maximum DER obtained from PT. Jababeka Industrial Estate Tbk in 2017 was due to a increase in long-term liabilities which came from bank loans and debt of finance lease. The minimum DER obtained from PT. Hanjaya Mandala Sampoerna in 2017 and 2018, this happened because the company adjusted the amount of dividends paid to shareholders, issued new shares and sold company's assets to pay debt, this also proves the company's solid ability to finance growth through internal sources.

Regression 1 is a model without use control variable, while regression 2 is a model with use control variable are shown in table 3.

Table 3. The Regression Result

\begin{tabular}{|c|c|c|c|c|}
\hline \multirow{3}{*}{ Variable } & \multicolumn{4}{|c|}{ Executive Compensation } \\
\hline & \multicolumn{2}{|c|}{ Regression 1} & \multicolumn{2}{|c|}{ Regression 2} \\
\hline & Coefficient & Prob & Coefficient & Prob \\
\hline $\mathrm{C}$ & 22,5121 **** & 0,0000 & 22,1327 ***** & 0,0000 \\
\hline Profitability & $-0,01211 * * *$ & 0,0009 & $-0,0098 * * *$ & 0,0097 \\
\hline Leverage & $-0,467629$ & 0,0523 & $-0,39047 *$ & 0,1040 \\
\hline CEO_Age & - & - & $0,01837 *$ & 0,0665 \\
\hline CEO_Gender & - & - & $-0,807316^{*}$ & 0,0823 \\
\hline CEO_Tenure & - & - & 0,013342 & 0,4542 \\
\hline $\mathrm{R}^{2}$ & \multicolumn{2}{|c|}{0,902596} & \multicolumn{2}{|c|}{0,906691} \\
\hline Adj $R^{2}$ & \multicolumn{2}{|c|}{0,852541} & \multicolumn{2}{|c|}{0,855734} \\
\hline Model & \multicolumn{2}{|c|}{ Fixed Effect Model } & \multicolumn{2}{|c|}{ Fixed Effect Model } \\
\hline Observation & 219 & 219 & 219 & 219 \\
\hline
\end{tabular}

The empirical evidence shows in the first regression, ROA without control variable has negative coefficient $(\beta=-0.01211)$ but significant $(p<0.01)$. Consistent with the first regression, the second regression show that ROA with control variables has negative coefficient $(\beta=-0.0098)$ but significant $(p<0.01)$. In the first regression, Leverage without control variable has negative coefficient $(\beta=-0.467629)$ and significant $(p<0.10)$ and consistent in the second regression, Leverage with control variables has negative coefficient $(ß=-0.39047)$ and significant $(p<0.10)$. 


\section{DISCUSSION}

In the first regression, profitability without control variable has negative significant relationship, and consistent with first regression, in the second regression also shows profitability with control variable has a negative significant impact on executive compensation. The findings confirm the previous research on the relationship profitability and executive compensation relationship (Lin et al (2018), Kazan et al (2016), Yousuf \& Kaysher (2016). Then, the results dispute the positive impact of the profitability on the executive compensation. Perhaps, the executive compensation was set by stockholder meeting on the previous year (Chou \& Buchdadi, 2018) .

Moreover, In the first regression of leverage without control variable has a negative significant relationship, and the second regression show the same result that leverage with control variable has a negative significant relationship. These findings show that the lower level of the company's debt, the larger the amount of executive compensation. This finding is supported by Ullah et al (2020) and Rodrigues et al (2017). It means the companies without pressure on the debt interest could give higher compensation on the executives.

\section{CONCLUSION}

This study used sample of non financial companies listed in Indonesia Stock Exchange for the period 2017 - 2019. The findings have shown that profitability has a negative significant effect on executive compensation. It is also noted that the lower level of the company's debt, the larger the amount of executive compensation. These findings shed the light on research on agency theory that compensation on performance is not valid in Indoesia. Moreover, the role of leverage on limit the executive compensation could the good topic in the future.

\section{RECOMMENDATION}

The limitation on this research that the executive compensation consist of basic salary, allowances and bonuses reported in the annual report. Probably it is better to redefine the executive compensation as the cash compensation only or bonus only. In addition, we encourage to conduct research with different span time for compensation and performance, such compensation current year as the determinant of the performance the next year and, or the performance of current year as the determinant the compensation of the next year.

\section{REFERENCES}

Arief, I. A. (2019). Taksi Express Rugi Rp 836 M, Direksi Dapat Remunerasi $R p \quad 6 \quad M$. CNBC Indonesia. http://www/cnbcindonesia.com/market/20190429211426-1769572/taksi-express-rugi-rp-836-m-direksi-dapat-remunerasirp-6-m

Buigut, K. K., Soi, N. C., \& Koskei, I. J. (2015). Determinants of CEO 
Compensation Evidence from UK Public Limited Companies. International Journal of Business and Management, 10(1), 223 230. https://doi.org/10.5539/ijbm.v10n1p223

Chou, T. K., \& Buchdadi, A. D. (2018). Executive's compensation, good corporate governance, ownership structure, and firm performance: A study of listed banks in Indonesia. Journal of Business and Retail Management Research, 12(3), 79-91. https://doi.org/10.24052/jbrmr/v12is03/art-07

Conyon, M., He, L., \& Zhou, X. (2015). Star CEOs or Political Connections? Evidence from China's Publicly Traded Firms. Journal of Business Finance and Accounting, 42(3-4), 412443. https://doi.org/10.1111/jbfa.12110

Dahiya, S. (2018). A Model of Managerial Compensation, Firm Leverage and Credit Stimulus. September, 1-35.

Emre, K. (2016). The impact of CEO compensation firm performance in Scandinavia. University of Twente, $0(0), 1-10$. https://essay.utwente.nl/71332/1/Kazan_BA_MB.pdf

Essen, M. Van, Otten, J., \& Carberry, E. J. (2015). Assessing Managerial Power Theory: A Meta-Analytic Approach to Understanding the Determinants of CEO Compensation. Journal of Management, 41(1), 164-202. https://doi.org/10.1177/0149206311429378

Field, L. C., Souther, M. E., \& Yore, A. S. (2016). Does Diversity Pay In The Boardroom?

Firth, M., Gao, J., Shen, J., \& Zhang, Y. (2016). Institutional stock ownership and firms' cash dividend policies: Evidence from China. Journal of Banking and Finance, 65, 91-107. https://doi.org/10.1016/j.jbankfin.2016.01.009

Friana, H. (2019). Dirut Garuda Hidup Bermewah - mewahan, Tapi Punya Karyawan Sengsara. Tirto.Id. https://www.google.com/amp/s/amp.tirto.id/dirut-garudahidup-bermewah-mewahan-tapi-punya-karyawan-sengsaraemWV

Hakim, L., \& Sugianto. (2018). Determinant Profitability and Implications on the Value of the Company : Empirical Study on Banking Industry in IDX. International Journal of Economics and Financial Issues, 8(1), 205-216.

Harun, M. Y., \& Hamid, M. K. (2016). The Relationship between CEO Compensation and Firm Performance in the Banking Sector of Bangladesh. AIUB Journal of Business and Economics, 13(1), 19-43.

Khanna, V. (2016). Determinants of CEO Compensation. International Journal of Management Excellence, 6(2), 679- 
683. https://doi.org/10.17722/ijme.v6i2.823

Lin, H., Liang, S., Chiu, S., \& Chen, C. (2018). Leverage and employee compensation - the perspective of human capital. International Journal of Managerial Finance, 1-18. https://doi.org/10.1108/JJMF-11-2017-0247

Lin, Kuo, H., \& Wang, L. (2013). Chief Executive Compensation : an Empirical Study Of Fat Cat CEOs. The International Journal of Business and Finance Research, 7(2), 27-43.

Locke, T. (2020). Average CEO Pay Increased 14\% in 2019 to $\$ 21.3$ Million - And Could Rise Again In 2020 Despite The Pandemic. CNBC.Com. https://www.cnbc.com/2020/08/19/studyaverage-ceo-pay-increased-in-2019-to-21 point3-milliondollars.html

Mardiyati, U., Devi, M. S., \& Suherman. (2013). Pengaruh Kinerja Perusahaan, Corporate Governance, dan Shareholder Payout Terhadap Kompensasi Eksekutif (The Impact of firms performance, Corporate governance, and shareholder payout on executives compensation). Jurnal Riset Manajemen Sains Indonesia (JRMSI), 4(2), 167-183. http://journal.unj.ac.id/unj/index.php/jrmsi/article/view/784

McGregor, J. (2020). Average CEO Earnings Soared To \$21.3 Million Last Year And Could Rise Again In 2020 Despite The Coronavirus Recessiontle. Washingtonpost.Com. https://www.google.com/amp/s/www/washingtonpost.com/bus iness/2020/08/18/corporate-executive-payincrease $/ \% 3$ FoutputType $=$ amp

Parimana, K. A. S., \& Wisadha, I. G. S. (2015). Pengaruh Privatisasi, Kompensasi Manajemen Eksekutif, dan Ukuran Perusahaan pada Kinerja Keuangan. E-Jurnal Akuntansi Universitas Udayana, 10.3, 753-762.

Parthasarathy, A., Bhattacherjee, D., \& Menon, K. (2011). Executive Compensation, Firm Performance and Corporate Governance: An Empirical Analysis. SSRN Electronic Journal, January, 135. https://doi.org/10.2139/ssrn.881730

Rodrigues, C. F. S. D., \& Simões. (2017). Executive Compensation: Does Firm Performance Impact Executive Salaries? The Cases of UK, Portugal, Spain and Sweden and Denmark (Issue January). School of Business and Economics.

Setyawan, A. M., \& Devie. (2017). Pengaruh CEO Duality Terhadap Firm Value Dengan Financial Performance Sebagai Variabel Intervening. Business Accounting Review, 4(1), 325-335.

Shah, S. Z. A., Javed, T., \& Abbas, M. (2019). Determinants Of CEO Compensation Empirical Evidence From Pakistani Listed 
Companies. International Research Journal of Finance and Economics, 32(October), 148-159.

Sheikh, M. F., Shah, S. Z. A., \& Akbar, S. (2018). Firm Performance, Corporate Governance And Executice Compensation In Pakistan. Applied Economics, 50(18), 2012-2027. https://doi.org/10.1080/00036846.2017.1386277

Ullah, F., Jiang, P., Shahab, Y., Li, H. X., \& Xu, L. (2020). Block Ownership And CEO Compensation: Does Board Gender Diversity Matter? Applied Economics, 52(6), 583-597. https://doi.org/10.1080/00036846.2019.1659490

Wang, H. C., Venezia, C. C., \& Yung, I. Lou. (2013). Determinants of Chief Executive Officer Compensation. Industrial and Labor Relations Review, 41(2), 215. https://doi.org/10.2307/2523632 